\title{
STUDI PENCEMARAN LOGAM BERAT KADMIUM (Cd) PADA PERMUKAAN DAN SEDIMEN DI PERAIRAN PANTAI TIDORE KOTA TIDORE KEPULAUAN
}

\author{
Oleh \\ Ainuddin \\ ahmad ainuddin@yahoo.co.id \\ Program Studi Ilmu Kelautan Fakulktas Ilmu Kelautan Universitas Nuku
}

\begin{abstract}
ABSTRAK
Penelitian ini dilakukan untuk mengetahui konsentrasi logam berat kadmium $(\mathrm{Cd})$ pada permukaan perairan dan pada sedimen dan sekaligus untuk mengetahui kualitas air di perairan Pantai Tidore Kota Tidore Kepulauan. Penelitian ini dilakukan pada 3 stasiun yaitu di Pelabuhan Rum , Pelabuhan Goto dan Pangkalan Pendaratan Ikan (PPI) Kota Tidore Kepulauan.

Penelitian ini merupakan penelitian survey dan laboratorium, dimana pengambilan sampel dilakukan secara langsung di lapangan kemudian dianalisis menggunakan Spektrofotometrik Serapan Atom (SSA) yang dilakukan di Laboratorium Balai Teknik Kesehatan Lingkungan dan Pemberantasan Penyakit Menular Kelas I Manado.

Berdasarkan hasil pengukuran kualitas perairan di lokasi penelitian ditinjau dari parameter fisika kimia umumnya masih layak untuk kehidupan bagi organisme perairan atau biota laut demikian pula konsentrasi dan bahan pencemar logam berat kadmium (Cd) yang ditemukan baik pada permukaan perairan maupun sedimen di perairan Kota Tidoe Kepulauan sesuai uji laboratorium nilai konsentrasinya masih dibawah ambang batas (NAB) yang diperkenankan.
\end{abstract}

Kata Kunci : Pelabuhan Rum, Pelabuhan Goto, Pangkalan Pendaratan Ikan (PPI), Spektrofotometrik Serapan Atom (SSA).

\section{A. PENDAHULUAN}

\section{Latar Belakang}

Pencemaran laut adalah masuknya atau dimasukkannya zat atau energi oleh manusia baik secara langsung maupun tidak langsung ke dalam lingkungan laut yang menyebabkan efek merugikan karena merusak sumberdaya hayati, membahayakan kesehatan manusia, menghalangi aktivitas di laut termasuk perikanan, menurunkan mutu air laut yang digunakan dan mengurangi kenyamanan di laut (GESAMP, 1986) dan menurut Palar (2008), bahwa Pencemaran atau polusi adalah suatu kondisi yang telah berubah dari bentuk asal pada keadaan yang lebih buruk. Pergeseran bentuk tatanan dari kondisi asal pada kondisi yang buruk ini dapat terjadi sebagai akibat masukan dari bahan-bahan pencemar atau polutan. Bahan polutan tersebut pada umumnya mempunyai sifat racun (toksik) yang berbahaya bagi organisme hidup. Toksisitas atau daya racun dari polutan itulah yang kemudian menjadi pemicu terjadinya pencemaran. Salah satu bahan pencemar yang sangat tinggi daya racunnya adalah kadmium $(\mathrm{Cd})$.

Logam kadmium $(\mathrm{Cd})$ dapat masuk ke lingkungan, terutaman sekali merupakan efek samping dari aktivitas yang dilakukan manusia. Boleh dikatakan bahwa semua bidang industri yang melibatkan $\mathrm{Cd}$ dalam proses operasional industrinya menjadi sumber pencemar. Termasuk didalamnya adalah air buangan rumah tangga (Palar, 2008). Kemudian dikemukakan lagi oleh Palar (2008) bahwa sama halnya merkuri dan logam-logam berat lannya, logam $\mathrm{Cd}$ membawa sifat racun yang sangat merugikan bagi semua organism hidup, bahkan juga sangt berbahaya untuk manusia.

Pelabuhan Rum, Pelabuhan Goto dan Pangkalan Pendarata Ikan (PPI) merupakan daerah pusat penyeberangan laut dan tempat pendaratan ikan yang ada di Kota Tidore Kepulauan sehinga sangat terbuka peluang atau menjadi indikator untuk menghasilkan logam-logam berbahaya secara langsung maupun tidak langsung terbuang ke laut sehingga dapat diduga akan mempengaruhi 
kualitas air dan sedimen di daerah sekitar pelabuhan tersebut.

Maraknya masyarakat sekitar pelabuhan yang mengonsumsi biota baik pada permukaan perairan maupun yang berada didasar atau sedimen sekitar perairan sangat memungkinkan terakumulasinya sejumlah bahan-bahan pencemar yang terkandung dalam tubuh biota yang dikonsumsi oleh manusia, dimana telah tercemar logam berat kadmium (Cd). Berdasarkan latar belakang diatas maka penulis telah melakukan penelitian dengan judul "Studi Pencemaran Logam Berat Kadmium (Cd) Pada Permukaan dan Sedimen di Perairan Pantai Tidore Kota Tidore Kepulauan

\section{Rumusan Masalah}

Adapun permasalahan penelitian ini adalah:

a. Berapa besar konsentrasi/kandungan bahan pencemar logam berat kadmium (Cd) di permukaan perairan dan sedimen di Perairan Pantai Kota Tidore Kepulauan?

b. Bagaimana keadaan kualitas air di perairan Pantai Tidore kota Tidore Kepulauan?

\section{Tujuan Penelitian}

Penelitian ini bertujuan untuk:

a. Untuk mengetahui konsentrasi/kandungan logam berat kadmium (Cd) di perairan Pantai Tidore Kota Tidore Kepulauan.

b. Untuk mengetahui kualitas air di perairan Pantai Tidore Kota Tidore Kepulauan.

\section{B. LANDASAN TEORI}

\section{Pengertian Pencemaran}

Pencemaran lingkungan adalah peristiwa penyebaran bahan kimia dengan kadar tertentu yang dapat merubah kadar keseimbangan pada daur materi, baik keadaan struktur maupun fungsinya, sehingga mengganggu kesejahteraan manusia. Pencemaran lingkungan menimbulkan gangguan terhadap kesejahteraan bahkan dapat berakibat fatal terhadap jiwa manusia (Harjadi, 1986).

Odum (1971) mengatakan bahwa pencemaran perairan adalah suatu perubahan fisika, kimia dan biologi yang tidak dikehendaki pada ekosistem perairan yang akan menimbulkan kerugian pada sumber kehidupan, kondisi kehidupan dan proses industri. Sedangkan berdasarkan Peraturan Pemerintah No.19/1999, pencemaran laut diartikan dengan masuknya atau dimasukkannya makhluk hidup, zat, energi, dan/atau komponen lain ke dalam lingkungan laut oleh kegiatan manusia sehingga kualitasnya turun sampai ke tingkat tertentu yang menyebabkan lingkungan laut tidak sesuai lagi dengan baku mutu dan/atau fungsinya.

\section{Sumber Pencemaran}

Sumber pencemar dapat dibedakan menjadi sumber domestik (rumah tangga) yaitu dari perkampungan, kota, pasar, jalan, terminal, rumah sakit, dan sebagainya, serta sumber non domestik, yaitu dari pabrik, industri, pertanian, peternakan, perikanan, transportasi, dan sumber-sumber lainnya. Sedangkan bentuk pencemar dapat dibagi menjadi bentuk cair, bentuk padat, bentuk gas dan kebisingan (Tresna, 1991).

Lingkungan perairan seringkali tercemar oleh limbah, baik limbah rumah tangga, limbah pertanian, maupun limbah industri. Limbah rumah tangga dapat berupa detergen dan sampah. Limbah pertanian, dapat berupa pupuk, pestisida, dan bahan pencemar lainnya. Adapun limbah industri, dapat berupa bahan-bahan kimia (Kordi, 2005).

Banyak aktifitas manusia yang secara tidak langsung menyebabkan kerusakan sumberdaya hayati perikanan. Misalnya perusakan hutan yang menyebabkan erosi dapat mendangkalkan dan merubah kondisi perairan. Pembuangan sampah dan kotoran yang berasal dari perumahan, pasar dan kota secara langsung memberi andil terhadap polusi perairan. Demikian juga sampah yang berasal dari berbagai industri dari hari ke hari akan menyebabkan tumpukan bermacammacam faktor penyebab berkurangnya hasil produksi perairan (Nontji, 2002).

\section{Logam Berat}

Logam adalah unsur alam yang dapat diperoleh dari laut, erosi batuan tambang, vulkanisme dan sebagainya (Clark, 1986). Umumnya logam-logam di alam ditemukan dalam bentuk persenyawaan dengan unsur lain, sangat jarang yang ditemukan dalam elemen tunggal. Unsur ini dalam suhu kamar 
tidak selalu berbentuk padat melainkan ada yang berbentuk cair,

Razak (1998) mengatakan bahwa dalam perairan, logam berat dapat ditemukan dalam bentuk terlarut dan tidak terlarut. Logam berat terlarut adalah logam yang membentuk kompleks dengan senyawa organik dan anorganik, sedangkan logam berat yang tidak terlarut merupakan partikelpartikel yang berbentuk koloid dan senyawa kelompok metal yang teradsorbsi pada partikel-partikel yang tersuspensi.

Menurut Vouk (1986), terdapat 80 jenis dari 109 unsur kimia di muka bumi ini yang telah teridentifikasi sebagai jenis logam berat. Berdasarkan sudut pandang toksikologi, logam berat ini dapat dibagi dalam dua jenis. Jenis pertama adalah logam berat esensial, di mana keberadaannya dalam jumlah tertentu sangat dibutuhkan oleh organisme hidup, namun dalam jumlah yang berlebihan dapat menimbulkan efek racun. Contoh logam berat ini adalah $\mathrm{Zn}, \mathrm{Cu}, \mathrm{Fe}, \mathrm{Co}, \mathrm{Mn}$ dan lain sebagainya. Sedangkan jenis kedua adalah logam berat tidak esensial atau beracun, di mana keberadaannya dalam tubuh masih belum diketahui manfaatnya atau bahkan dapat bersifat racun, seperti $\mathrm{Hg}, \mathrm{Cd}, \mathrm{Pb}, \mathrm{Cr}$ dan lain-lain. Logam berat ini dapat menimbulkan efek kesehatan bagi manusia tergantung pada bagian mana logam berat tersebut terikat dalam tubuh. Daya racun yang dimiliki akan bekerja sebagai penghalang kerja enzim, sehingga proses metabolisme tubuh terputus. Lebih jauh lagi, logam berat ini akan bertindak sebagai penyebab alergi, mutagen, teratogen atau karsinogen bagi manusia. Jalur masuknya adalah melalui Kulit, pernapasan dan pencernaan.

Kadmium adalah logam kebiruan yang lunak, termasuk golongan II B tabel berskala dengan konfigurasi elekron $[\mathrm{Kr}] 4 \mathrm{~d}^{10} 5 \mathrm{~s}^{2}$ unsur ini bernomor atom 48, mempunyai bobot atom $112,41 \mathrm{~g} / \mathrm{mol}$ dan densitas $8,65 \mathrm{~g} / \mathrm{cm}^{3}$. Titik didih dan titik lelehnya berturut-turut $765^{\circ} \mathrm{C}$ dan $320,9^{0} \mathrm{C}$. Kadmium merupakan racun yang berasal dari daratan masuk ke laut dengan jalan faktor alam dan manusia, sehingga perairaan dapat tercemar oleh logam berat kadmium, dalam tubuh manusia sebagian besar diperoleh melalui makanan kadmium yang terdapat perairan sebagian besar diperoleh melalui pembuangan limbah rumah tangga, dan tumpahan minyak, hanya sejumlah kecil berasal dari air minum dan polusi udara. Pemasukan $\mathrm{Cd}$ melalui daratan adalah $10-40 \mu \mathrm{g} / \mathrm{hari}$, sedikitnya $50 \%$ diserap oleh organisme yang hidup di sekitarnya (Laegreid dkk, 1999).

Logam Cd atau kadmium mempunyai penyebaran yang sangat luas di alam. Berdasarkan sifat-sifat fisiknya, $\mathrm{Cd}$ merupakan logam yang lunak ductile, berwarna putih seperti putih perak. Logam ini akan kehilangan kilapnya bila berada dalam udara yang basah atau lembab serta cepat akan mengalami kerusakan bila dikenai uap amoniak $\left(\mathrm{NH}_{3}\right)$ dan sulfur hidroksida $\left(\mathrm{SO}_{2}\right)$. Sedangkan berdasarkan pada sifat kimianya, logam $\mathrm{Cd}$ di dalam persenyawaan yang dibentuk umumnya mempunyai bilangan valensi $2+$, sangat sedikit yang mempunyai bilangan valensi 1+. Bila dimasukkan ke dalam larutan yang mengandung ion $\mathrm{OH}$, ion-ion $\mathrm{Cd}^{2+}$ akan mengalami proses pengendapan. Endapan yang terbentuk dari ion-ion $\mathrm{Cd}^{2+}$ dalam larutan $\mathrm{OH}$ biasanya dalam bentuk senyawa terhidrasi yang berwarna putih (Palar, 2008).

\section{Dampak Pencemaran logam berat kadmium (Cd) Terhadap Lingkungan Perairan dan Organisme}

Keracun Kadmium (Cd) awalnya dimulai dengan perubahan warna kuning pada gigi, kemudian diikuti gangguan pada rongga hidung, bersin, hilangnya indra penciuman, dan mulut menjadi kering. Tanda-tanda yang paling khas dari penyakit ini adalah nyeri pada punggung dan otot kaki. Logam berat $\mathrm{Cd}$ kadmium paling banyak dalam bentuk $\mathrm{Cd}$ bervalensi $\mathrm{H}$, yang berikatan dengan gugus anorganik (halida, oksida, sulfida). Kadmium (Cd) dengan gugusan karbonat, sulfida dan hidroksida mempunyai kelarutan yang sangat rendah sehingga kadmium (Cd) di lingkungan perairan banyak terdapat dalam sedimen (Laegreid dkk, 1999).

Seperti halnya merkuri dan logamlogam lainnya, logam $\mathrm{Cd}$ membawa sifat beracun yang sangat merugikan bagi semua organisme hidup, bahkan juga sangat berbahaya untuk manusia. Dalam badan perairan, kelarutan $\mathrm{Cd}$ dalam konsentrasi tertentu dapat membunuh biota perairan. Biota-biota yang tergolong bangsa udangudangan (crustacea) akan mengalami kematian dalam selang waktu 24-504 jam bila dalam badan perairan di mana biota ini hidup 
terlarut logam atau persenyawaan $\mathrm{Cd}$ pada rentang konsentrasi 0,005-0,15 ppm. Sedangkan untuk biota-biota perairan yang tergolong ke dalam keluarga Oligichaeta akan mengalami kematian dalam selang waktu 24672 jam bila ditemukan dalam badan perairan di mana biota-biota tersebut hidup terlarut logam $\mathrm{Cd}$ dan atau persenyawaannya dalam rentang konsentrasi 0,0028-4,6 ppm (Palar,2008). Kemudian dilanjutkan kembali oleh Palar (2008) bahwa jika logam Cd akan mengalami proses biotransformasi dan bioakumulasi dalam organisme hidup (tumbuhan, hewan dan manusia). Logam ini masuk ke dalam tubuh bersamaan makanan yang dikomsumsi yang telah terkontaminasi oleh logam Cd dan persenyawaannya. Dalam tubuh biota perairan jumlah logam yang terakumulasi akan terus mengalami peningkatan dengan adanya proses biomagnifikasi di badan perairan. Bila jumlah $\mathrm{Cd}$ yang masuk tersebut telah nilai melebihi ambang batas maka biota akan mengalami kematian dan bahkan kemusnahan.

\section{Parameter Kualitas Air}

\section{a. pH (Derajat Keasaman)}

$\mathrm{pH}$ adalah istilah yang digunakan untuk menyatakan intensitas keadaan asam atau basa suatu larutan. $\mathrm{pH}$ juga merupakan suatu cara untuk menyatakan konsentrasi ion $\mathrm{H}$. Asam adalah senyawa yang menghasilkan ion hydrogen $(\mathrm{OH})$ bila dilarutkan dalam air, sedangkan basa adalah senyawa-senyawa yang menghasilkan ion hidroksil $\left(\mathrm{OH}^{-}\right)$. $\mathrm{H}$ dan $\mathrm{OH}^{-}$berasal dari ionisasi molekul $\mathrm{HO}$ (Soetomo H.A., 1990 dalam Kordi, 2005).

b. Salinitas

Salinitas atau kadar garam air biasanya didefinisikan sebagai jumlah (dalam garam) dari total garam terlarut yang ada dalam 1 kilogram air laut dan biasanya diukur dengan konduktivitas. Semakin tinggi konduktifitas semakin tinggi kadar garamnya. Komposisi kadar garam tersebut selalu dalam keadaan yang konstan dalam jangka waktu yang panjang. Hal ini disebabkan karena adanya kontrol dari berbagai proses kimia dan biologi di dalam perairan laut. Kondisi ini menyebabkan sebagian besar organisme yang hidup diperairan laut merupakan organisme yang memiliki toleransi (sensitivitas) terhadap perubahan salinitas yang sangat kecil atau organisme yang diklasifikasikan sebagai organisme stenohalin (Widodo dan Suadi, 2006).

\section{c. DO (Oksigen Terlarut)}

Tresna (1991), dalam air deras biasanya oksigen tidak menjadi faktor pembatas. Dalam sungai yang jernih dan deras kepekatan oksigen mencapai kejenuhan. Jika air berjalan lambat atau ada pencemar maka oksigen yang terlarut mungkin dibawah kejenuhan, sehingga oksigen kembali menjadi faktor pembatas kepekatan oksigen terlarut bergantung kepada:

1) suhu

2) kehadiran tanaman fotosintesis

3) tingkat penetrasi cahaya yang tergantung kepada kedalaman dan kekeruhan air,

4) tingkat kederasan aliran air

5) jumlah bahan organik yang di uraikan dalam air, seperti sampah, gangang mati, atau limbah industri.

\section{d. Suhu}

Suhu mempengaruhi aktifitas metabolisme organisme, karena itu penyebaran organisme baik di lautan maupun di perairan tawar dibatasi oleh suhu perairan tersebut. Suhu sangat berpengaruh terhadap kehidupan dan pertumbuhan ikan. Secara umum laju pertumbuhan meningkat sejalan dengan kenaikan suhu, dapat menekan kehidupan ikan bahkan menyebabkan kematian bila peningkatan suhu sampai ekstrem (drastis) (Kordi, 2005).

Nybakken (1988) menjelaskan bahwa suhu merupakan salah satu faktor yang sangat penting dalam mengatur proses kehidupan dan penyebaran organisme. Kaidah umum menyebutkan bahwa reaksi kimia dan biologi air (proses fisiologis) akan meningkat 2 kali lipat pada kenaikan temperatur $10^{\circ} \mathrm{C}$, selain itu suhu juga berpengaruh terhadap penyebaran dan komposisi organisme. Kisaran suhu yang baik bagi kehidupan organisme perairan adalah antara $18-30^{\circ} \mathrm{C}$. 


\section{METODE PENELITIAN}

\section{Rancangan Penelitian}

Penelitian ini menggunakan metode analisis deskriptif kualitatif.

\section{Alat dan Bahan}

Alat dan bahan dalam penelitian ini dapat dilihat pada tabel berikut:

Tabel 1.

Alat dan bahan penelitian

\begin{tabular}{clcl}
\hline No & \multicolumn{1}{c}{ Alat/Bahan } & Satuan & \multicolumn{1}{c}{ Kegunaan } \\
\hline 1 & Sedimen core & - & Pengambilan sampel sedimen \\
2 & Water quality checker & - & Mengukur pH, DO \\
3 & Coolbox & - & Tempat penyimpanan sampel \\
4 & Botol sampel & $\mathrm{ml}$ & Sebagai wadah sampel air laut \\
5 & Hand Refractometer & $\mathbf{\%}$ & Mengukur salinitas \\
6 & Termometer & ${ }^{\circ} \mathrm{C}$ & Untuk mengukur suhu perairan \\
7 & Aquades & $\mathrm{ml}$ & Untuk menetralisir alat \\
& $\mathrm{H}_{2} \mathrm{SO}_{4}$ & $\mathrm{ml}$ & Pengawet Sampel air \\
8 & Tissu & pack & Mengeringkan alat \\
8 & Perahu/katinting & unit & Mengambil sampel dilaut \\
9 & Papan LJK & - & Pengalas lembar data \\
10 & Pena & - & Untuk mencatat data \\
11 & Kamera & Unit & Dokumentasi Penelitian \\
12 & SSA Shimadzu & Unit & Menganalisis sampel air \\
13 & Peta & Skala & Penunjuk lokasi penelitian \\
14 & Sampel air laut dan sedimen & $\mathrm{ml}$ & Sebagai bahan uji di laboratorium \\
\hline
\end{tabular}

\section{Lokasi Penelitian}

Penelitian ini dilaksanakan pada tiga lokasi atau tiga stasiun yaitu yang berada pada perairan pantai Tidore Kota Tidore Kepulauan. Ketiga stasiun itu adalah:

a. Stasiun I berada di Pelabuhan Goto

b. Stasiun II pada Pangkalan Pendaratan Ikan (PPI) Kota Tidore Kepulauan dan

c. Stasiun III berada pada Pelabuhan Rum.

\section{Teknik Pengambilan Sampel}

Penelitian ini dibagi dalam 3 stasiun. Masing-masing stasiun dilakukan pengukuran kualitas air seperti suhu, $\mathrm{pH}$ meter, salinitas, dan DO meter. Untuk pengukuran logam berat Cd maka masing-masing stasiun diambil sampelnya baik permukaan perairan maupun sedimen. Kemudian sampel ini di bawah ke laboratorium untuk analisis dengan menggunakan spektrofotometrik serapan atom (SSA) yang di lakukan di laboratorium Balai Teknik Kesehatan Lingkungan (BTKL) Manado dan hasil yang diperoleh dari laboratorium kemudian di analisis secara deskriptif kemudian disajikan dalam bentuk tabel dan grafik. Prosedur analisis dapat dilihat pada skema berikut:
Prosedur Analisis

$$
\begin{array}{|l|}
\hline \multicolumn{1}{|c|}{\text { SAMPEL SEDIMEN } 100 \mathrm{mg}} \\
\hline
\end{array}
$$

Gambara. 1. Skema prosedur analisis logam berat cadmium $(\mathrm{Cd})$ dengan Spektrofoto metrik Serap Atom

\section{HASIL DAN PEMBAHASAN}

\section{Analisis Kualitas Air}

Dalam rangka pengelolaan kualitas air dan atau pengendalian pencemaran air, perlu diketahui status mutu air (the state of the water quality). Untuk itu dilakukan pengukuran kualitas air guna mengetahui 
mutu air dengan membandingkannya dengan standar baku mutu air sesuai peraturan pemerintah yang berlaku. Untuk itu maka dilakukanlah pengukuran beberapa parameter lingkungan pada lokasi penelitian dengan hasil seperti pada table di bawah ini.

Tabel 2.

Hasil Pengukuran Kualitas Air di Tiap Stasiun

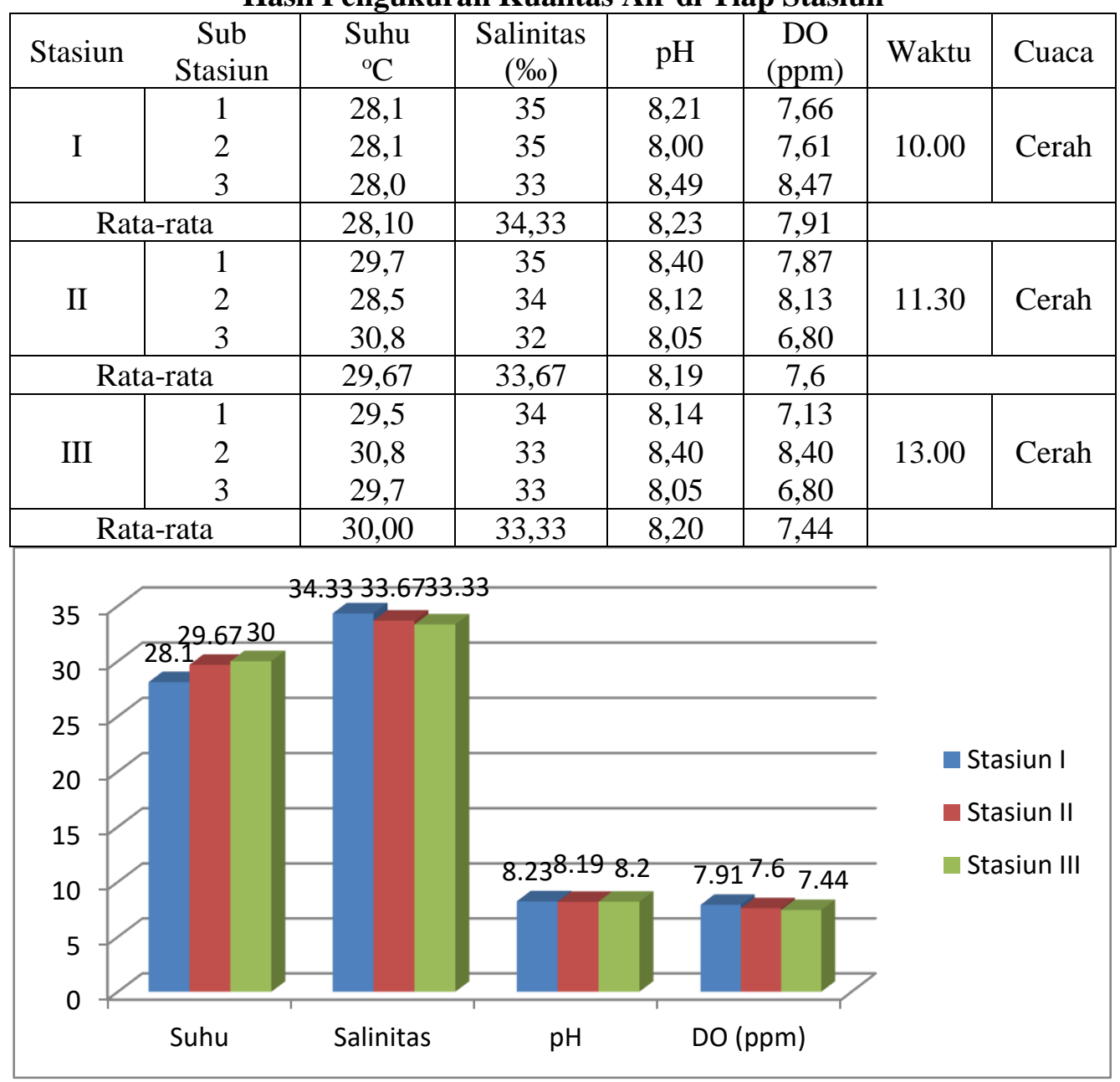

Gambar 2. Hasil Pengukuran Rata-rata Kualitas Air pada Lokasi Penelitian

\section{a. Suhu}

Berdasarkan Tabel 2 dan Gambar 2 di atas terlihat bahwa suhu rata-rata pada lokasi penelitian berkisar antara $28,1{ }^{\circ} \mathrm{C}$ sampai $30{ }^{\circ} \mathrm{C}$. Dimana suhu rata-rata terendah diperoleh dari stasiun I dengan suhu $28,1^{\circ} \mathrm{C}$ dan suhu tertinggi diperoleh pada stasiun III dengan suhu $30^{\circ} \mathrm{C}$.

Berdasarkan pernyataan Nybakken (1998) bahwa kisaran suhu yang baik bagi kehidupan organisme perairan adalah antara $18-30{ }^{\circ} \mathrm{C}$ maka dapat disimpulkan bahwa suhu yang ditemukan pada lokasi penelitian masih sesaui untuk kehidupan organisme perairan.

\section{b. Salinitas}

Dari Tabel 2 dan gambar 2 di atas terlihat pula bahwa rata-rata kisaran salinitas yang diperoleh pada lokasi penelitian adalah berkisar antara 33,33 \%o sampai 34,33\%o. Dimana rata-rata salinitas terendah diperoleh pada Stasiun III dengan nilai salinitas sebesar 33,33\% dan rata-rata salinitas terbesar diperoleh pada stasiun I dengan besaran $34.33 \%$.

Nilai salinitas yang baik untuk kehidupan biota baik hewan maupun tumbuhan di laut yang ditetapkan oleh Menteri Negara Lingkungan Hidup melalui ketetapan baku mutu air laut No. 51 Tahun 2004 adalah 33-34\%. Berdasarkan ketetapan ini maka dapat di simpulkan bahwa suhu rata-rata yang diperoleh pada 
lokasi penelitian masih sesuai untuk kehidupan biota baik hewan maupun tumbuhan.

c. $\mathbf{p H}$

$\mathrm{pH}$ yang ditemukan pada lokasi penelitian seperti terlihat pada Tabel 2 dan Gambar 2 ditas berkisisar antara 8,19 sampai 8,23. Dimana pH tertinggi diperoleh pada stasiun I dengan besaran $\mathrm{pH}$ rata-rata 8,23 dan terendah ditemukan pada stasiun II dengan $\mathrm{pH}$ rata-rata sebesar 8,19 (Tabel 2 dan Gambar 2). Berdasarkan baku mutu air menurut Kepmen LH No. 51 tahun 2004 mengatakan bahwa $\mathrm{pH}$ yang baik untuk mendukung kehidupan baik biota maupun organisme lainnya berkisar antara 6,5 - 8,5. Ini berarti bahwa $\mathrm{pH}$ yang ditemukan pada lokasi penelitian masih sesuai dengan stardar baku mutu air yang ditetapkan berdasarkan Kepmen LH No.51 tahun 2004.

\section{d. DO meter (oksigen terlarut)}

Oksigen terlarut yang ditemukan pada lokasi penelitian berdasarkan Tabel 2 dan Gambar 2 di atas berkisar antara 7,44 ppm sampai 7,91 ppm. DO tertinggi ditemukan pada stasiun I sebesar 7,91 dan terendah pada stasiun III dengan besaran 7,44.

Berdsasarkan kandungan DO menurut Lee et al. (1978) yang mengelompokkan kualitas perairan atas empat tingkatan yaitu tidak tercemar (> 6,5 ppm), tercemar ringan (4,5 - 6,5 ppm), tercemar sedang $(2,0$ - 4,4 ppm) dan tercemar berat ( $<2,0 \mathrm{ppm})$.

Berdasarkan pengelompokan kualitas perairan yang dikemukakan oleh Lee et al., (19768), maka kadar oksigen terlarut pada lokasi penelitian masuk kategori tidak tercemar. Dan menurut Menteri Negara Lingkungan Hidup (MNLH, 2004) tentang baku mutu air laut untuk biota laut bahwa nilai oksigen terlarut yang diperbolehkan adalah lebih dari 5 ppm, maka kada oksigen terlarut yang diperoleh pada lokasi penelitian menunjukkan bahwa masih layak untuk kehidupan biota laut.

\section{Analisis Logam Berat Kadmium (Cd)}

Tabel di bawah ini merupakan hasil pengukuran konsentrasi logam cadmium $(\mathrm{Cd})$ baik di perairannya maupun dalam sedimen yang diperoleh di perairan Pantai Tidore, Kota Todore Kepulauan.

Tabel 3.

Hasil Pengukuran Konsentrasi Logam Cd pada Lokasi Penelitian

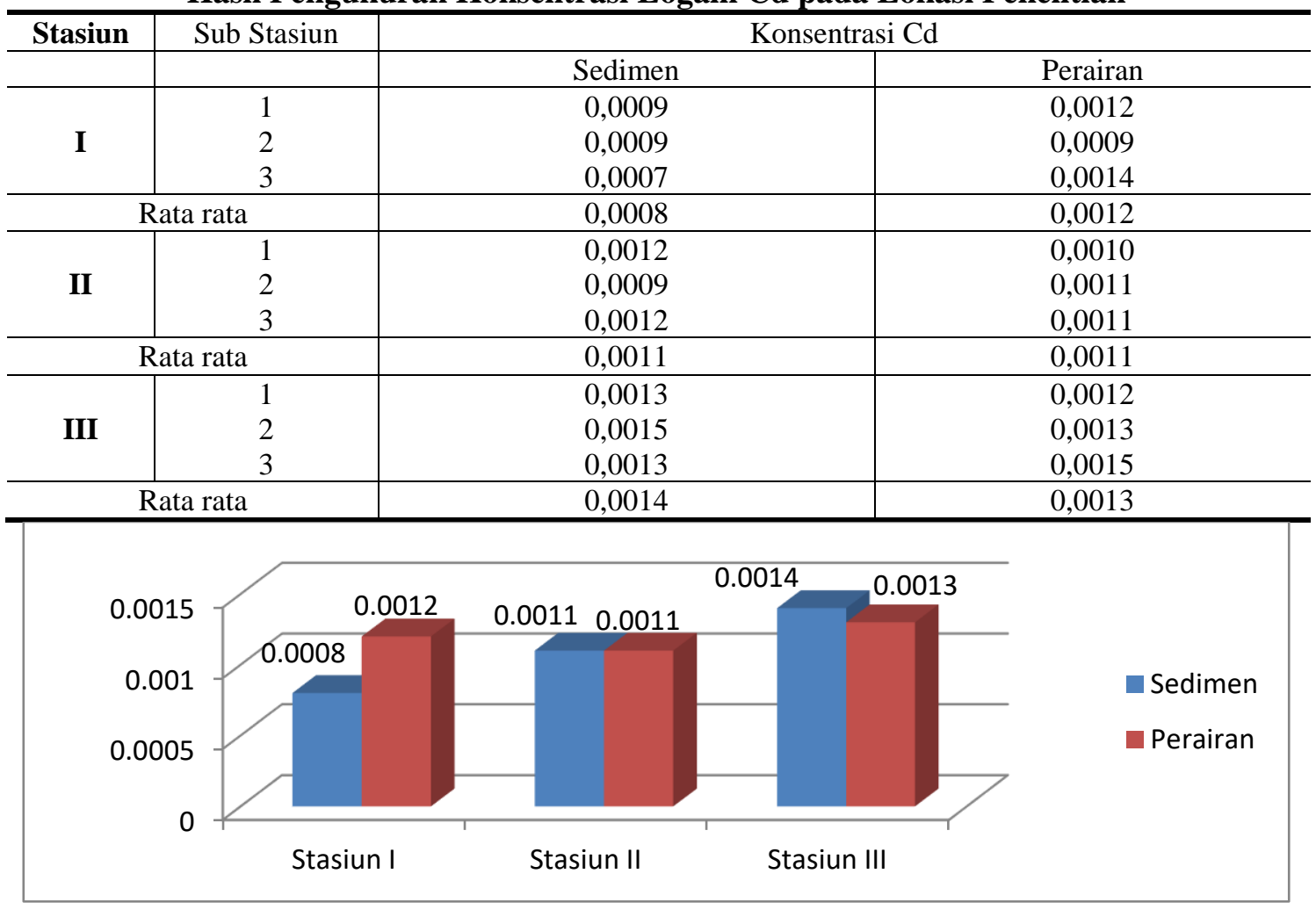

Gambar 3. Rata-Rata konsentrasi Cd pada Lokasi Penbelitian 
Berdasarkan Tabel 3 dan Gambar 3 di atas menunjukkan bahwa nilai rata-rata konsentrasi logam $\mathrm{Cd}$ pada lokasi penelitian berkisar antara 0,008 mg/l sampai 0,0014 $\mathrm{mg} / \mathrm{l}$ untuk Logam Cd yang ditemukan pada sedimen dan $0011 \mathrm{mg} / \mathrm{l}$ sampai $0,0013 \mathrm{mg} / \mathrm{l}$ untuk konsentrasi $\mathrm{Cd}$ yang ditemukan pada permukaan perairan di lokasi penelitian. Dengan konsentrasi $\mathrm{Cd}$ terbesar di temukan pada stasiun II dan yang terbesar di tenmukan pada stasiun III.

Berdasarkan Keputusan Menteri Negara Lingkungan Hidup (MNLH) No. 51 tahun 2004 tentang baku mutu air laut yang diperbolehkan untuk kehidupan biota laut tidak lebih dari $0,005 \mathrm{mg} / \mathrm{l}$ maka konsentrasi logam $\mathrm{Cd}$ yang diperoleh pada lokasi penelitian di Perairan Pantai Tidore, Kota Tidore Kepulauan baik pada permukaan perairan maupun pada sedimennya masih layak bagi kehidupan organieme laut.

\section{E. KESIMPULAN DAN SARAN}

\section{Kesimpulan}

Berdasarkan hasil dan pembahasan dapat ditarik kesimpulan sebagai berikut:

a. Konsentrasi Bahan pencemar logam berat kadmium (Cd) yang di peroleh pada perairan Pantai Tidore Kota Tidore Kepulauan masih layak untuk kehidupan organisme.

b. Kualitas perairan pada lokasi penelitian di tinjau dari parameter fisika-kimia umumnya masih layak bagi kehidupan organisme perairan.

\section{Saran}

Perlu dilakukan penelitian secara berkala tentang konsentrasi cadmium maupun logam berta lainnya untuk mendapatkan data yang lengkap pada perairan Pantai Kota Tidore Kepulauan.

\section{DAFTAR PUSTAKA}

Clark, R.B., 1986. Marine Pollution. Claredon Press, Oxford.

GESAMP (Group Expert on Scientific Aspect of Marine Pollution), 1986. Report of The Seven Session, WHO (World Health Organisation).
Harjadi W, 1986. Ilmu Kimia Analitik Dasar.Penerbit PT. Gramulia. Jakarta.

Kordi, M.G.H. 2005. Parameter Kualitas Air. Karya Andi, Surabaya.

Laegreid M, O.L, Bockman dan O, Kaarsstad. 1999, Agriculture, Fertilizers \& The Environment, Norway : Cabi Publishing.

Lee, C.D.., S.B. Wang and C.L. Kuo, 1978. Benthic Macroinvertebrate and Fish as Biological Indicator of Water Quality, with Reference to Community Diversity Index dalam E.A.R. Guano, B.N. Lokani and M.C. Thank (Ed). Water Pollution Control in Developing Countries, Asian Inst. Tech. Bang-kok. P:233-238.

Menteri Negara Lingkungan Hidup (MNLH). 2004. Keputusan Menteri Negara Lingkungan Hidup No. 51/2004 Tentang Baku Mutu Air Laut untuk Biota Laut. KLH, Jakarta.

Nontji, A. 2005. Laut Nusantara. Djambatan, Jakarta.

Nybakken JW. 1998. Biology Laut: Suatu Pendekatan Ekologis. PT. Gramedia. Jakarta.

Odum, E.P. 1971. Fundamental of Ecology. $3^{\text {rd }}$ Edition. W.B. Sounders Company. Philadelphia.

Palar, H., 2008. Pencemaran dan Toksikologi Logam Berat. Rineka Cipta, Jakarta.

PP Nomor 19 Tahun 1999 Tentang Pengendalian Pencemaran Dan/Atau Perusakan Laut. Jakarta.

Razak, T.B. 1998. Struktur Komunitas Karang Berdasarkan Metode Transek Garis dan Transek Kuadrat di Pulau Menyawakan Taman Nasional Karimun Jawa Jateng. Skripsi. Fakultas Perikanan dan Ilmu Kelautan, Institut Pertanian Bogor, Bogor.

Tresna, S.A., 1991. Pencemaran Lingkungan. Rineka Cipta. Jakarta.

Widodo, J., dan Suadi, 2006. Pengelolaan Sumberdaya Perikanan Laut.Gajah Mada University Press, Yogyakarta. 